\title{
Brand Relationship Pada Komunitas Marvel Indonesia (Studi Analisis Film Avengers: Endgame)
}

\author{
Ivander Wilson Saputra, Diah Ayu Candraningrum \\ ivanderwilsonsaputra@gmail.com; diahc@fikom.untar.ac.id \\ Fakultas Ilmu Komunikasi Universitas Tarumanagara
}

\begin{abstract}
This study aims to determine the perceptions that emerge as well as how much is the level of interests fans based Avengers movie. The theory used in this research is the theory of mass communication, film, brand, and brand relationship. The approach used in this research is a qualitative approach with a phenomenological method. The subject of the study was the Indonesian Marvel Community with the object of the film Avengers: Endgame. Data collection is conduct by online research, interviews, and literature study. The speakers in this study were community founders, film experts, business experts and Avengers fans. Data analysis using interactive data models and triangulation of source data with the results obtained. Based on the results of the study found that there is a relationship between an Avengers brand: Endgame with the Marvel Indonesia Community and its fans. This relationship has reached the level of best friends and crucial friends in responding Avengers movie. This strengthened by the crowded of Avengers audience and the purchase pioneer of merchandise.
\end{abstract}

Keywords: avengers, brand, brand relationship, communication, komunitas marvel indonesia.

\begin{abstract}
Abstrak
Penelitian ini bertujuan untuk mengetahui persepsi yang muncul serta seberapa besar ketertarikan penggemar terhadap film Avengers: Endgame. Teori yang digunakan dalam penelitian ini adalah teori komunikasi massa, film, brand, dan brand relationship. Pendekatan yang digunakan dalam penelitian ini adalah pendekatan kualitatif dengan metode fenomenologi. Subjek dari penelitian adalah Komunitas Marvel Indonesia dengan objek film Avengers: Endgame. Pengumpulan data dilakukan dengan cara riset online, wawancara, dan studi pustaka. Yang menjadi narasumber dalam penelitian ini adalah pendiri komunitas, pakar film, pakar bisnis dan penggemar Avengers. Analisis data menggunakan data model interaktif serta triangulasi data sumber dengan hasil yang telah didapat. Berdasarkan hasil penelitian ditemukan bahwa terciptanya hubungan antara sebuah brand Avengers: Endgame dengan Komunitas Marvel Indonesia serta penggemarnya. Hubungan ini telah mencapai tingkat best friends dan crucial friends dalam menyambut Avengers. Hal ini diperkuat dengan bioskop yang penuh serta penggemar yang sampai membeli atribut-atribut superhero kesayangannya.
\end{abstract}

Kata Kunci: avengers, brand, brand relationship, komunikasi massa, komunitas marvel indonesia

\section{Pendahuluan}

Seiring berkembangnya industri perfilman di dunia, semakin banyak film yang dibentuk dengan cara yang berbeda-beda. Menurut Pratista (2017) Sebuah film terbentuk dari dua unsur, yaitu unsur naratif dan unsur sinematik. Setiap film tidak mungkin lepas dari segi naratif dan setiap cerita pasti memiliki unsur-unsur seperti lokasi, masalah, waktu, tokoh, dan lainnya. Sedangkan unsur sinematik adalah yang 
mengolah unsur naratif untuk dibentuk menjadi sebuah film, unsur sinematik dibagi menjadi 4 elemen seperti mise-en-scene, sinematografi, editing dan audio.

Berdasarkan UU 8/1992 Pasal 1, film didefinisikan sebagai karya cipta seni dan budaya yang merupakan media komunikasi massa pandang-dengar yang dibuat berdasarkan asas sinematografi dengan direkam pada pita seluloid, pita video, piringan video, dan/atau bahan hasil penemuan teknologi lainnya dalam segala bentuk, jenis, dan ukuran melalui proses kimiawi, proses elektronik, atau proses lainnya, dengan atau tanpa suara, yang dapat dipertunjukkan dan/atau ditayangkan dengan sistem Proyeksi mekanik, elektronik, dan/atau lainnya; (Hukum Unsrat, n.d.).

Berdasarkan ceritanya, film dapat dibagi menjadi film fiksi dan non fiksi. Sumarno (2008) mendefinisikan fiksi adalah film yang dibuat atau diproduksi berdasarkan cerita yang dikarang dan dimainkan oleh aktor dan aktris. Sedangkan film non fiksi adalah film yang mengambil kenyataan sebagai subjeknya Kemudian dimasukkan ke unsur-unsur sinematografis dengan ditambahkan special effects tertentu seperti efek suara, musik, cahaya, komputerisasi, skenario atau naskah yang memikat dan lain sebagainya untuk mendukung daya tarik film non fiksi tersebut.

Di tahun 2019 ini terdapat Avengers: Endgame. Film ini adalah seri terakhir dari Avengers. Avengers: Endgame merupakan film superhero Amerika berdasarkan pada Marvel Comics the Avengers, diproduksi oleh Marvel Studios dan didistribusikan oleh Walt Disney Studios Motion Pictures. Ini adalah sekuel The Avengers 2012, Avengers: Age of Ultron 2015 dan Avengers: Infinity War 2018, dan film kedua puluh dua Marvel Cinematic Universe (MCU). Film ini disutradarai oleh Anthony dan Joe Russo, serta ditulis oleh Christopher Markus dan Stephen McFeely (Imdb, n.d.).

Avengers: Endgame berhasil memecahkan rekor sebagai film terlaris sepanjang masa. Seperti yang dilansir oleh CNN Indonesia bahwa film ini berhasil memperoleh total mencapai US\$2,7897 miliar atau setara dengan Rp39 triliun (CNN Indonesia, 2019).

Kesuksesan dari film Avengers: Endgame tersebut tidak terlepas dari Brand. Brand bukan hanya logo atau nama perusahaan saja, tapi tentang image atau persepsi seseorang tentang suatu produk. Menurut Keagan (1995), Merek sebagai sekumpulan citra dan pengalaman kompleks dalam benak pelanggan, yang mengomunikasikan harapan mengenai manfaat yang akan diperoleh dari suatu produk yang diproduksi oleh perusahaan tertentu (Sadat, 2009).

Berdasarkan dari kesuksesan film Avengers: Endgame, penulis ingin mengulik lebih dalam bagaimanakah hubungan yang terjalin dengan salah satu komunitas penggemar yaitu Komunitas Marvel Indonesia. Alasan penulis menggunakan KMI adalah karena merupakan komunitas penggemar marvel yang aktif dan yang terbesar sementara komunitas lainnya hanya parsial.

Tabel 1. Jumlah Komunitas Penggemar Parsial

\begin{tabular}{clcc}
\hline No & Nama & Platform & Jumlah Anggota \\
\hline 1 & $\begin{array}{l}\text { Komunitas Spider-Verse Indonesia } \\
\text { (Spiderman) }\end{array}$ & Facebook & $4000+$ \\
\hline 2 & $\begin{array}{l}\text { Iron Man Fans Club Indonesia (Iron } \\
\text { Man) }\end{array}$ & Facebook & $4000+$ \\
\hline 3 & $\begin{array}{l}\text { Guardian of The Marvel Galaxy } \\
\text { (GoTMG) }\end{array}$ & Facebook & $2000+$ \\
\hline
\end{tabular}




\begin{tabular}{cllc}
\hline 4 & Komunitas Thor Love Thunder (Thor) & $\begin{array}{l}\text { Forum } \\
\text { Kaskus }\end{array}$ & $300+$ \\
\hline 5 & I am Iron Man (Iron Man) & Facebook & $3000+$ \\
\hline 6 & Gamoniac (Gamora): & $\begin{array}{l}\text { Forum } \\
\text { Kaskus }\end{array}$ & $200+$ \\
\hline
\end{tabular}

\section{Sumber: Hasil Pencarian Penulis}

Seperti yang dilansir oleh Fimela.com, Berawal dari forum online, KMI didirikan pada Agustus 2009 oleh lima orang penggemar karya-karya Marvel. KMI berasal dari berbagai kota kemudian sepakat untuk membangun komunitas multiregional untuk para penggemar di seluruh Indonesia. Di media sosial, KMI telah memiliki ribuan anggota yang terdiri dari berbagai wilayah di Indonesia. Di antaranya Jakarta, Bandung, Surabaya, Medan, Jambi, Palembang, Samarinda, Manado dan Makasar (Cica, 2019).

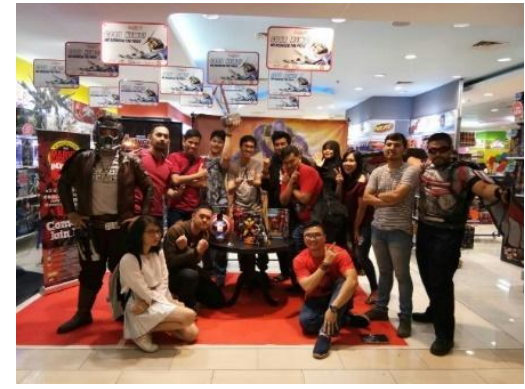

Gambar 1. Foto Event Komunitas Marvel Indonesia Sumber: Dok. Komunitas Marvel Indonesia

Seperti apa yang ditulis oleh Kabarinews.com, KMI mengadakan kegiatan rutin setiap bulan seperti gathering per-wilayah, promosi oleh beberapa pihak, undangan event, kegiatan cosplay tokoh marvel hasil kerja sama dengan sponsor dan beberapa perusahaan untuk promosi. Keanggotaan saat ini tidak ada yang membatasi, dari muda dewasa dan orang tua, kaum lelaki dan wanita bebas bergabung dengan. Cara untuk bergabung hanya dengan request to join di facebook (Prasetyo, 2014).

\section{Metode Penelitian}

Penelitian ini menggunakan pendekatan penelitian kualitatif dengan menggunakan metode fenomenologi untuk mempelajari proses dalam penelitian ini yaitu brand relationship. Fenomenologi menurut Moustakas adalah strategi penelitian yang mengidentifikasi hakikat tentang fenomena tertentu (Jesslyn dan Susanto, 2018). Subjek penelitian penulis adalah Komunitas Marvel Indonesia. Sementara objek penelitian adalah film Avengers: Endgame. Penulis menggunakan teknik pengambilan data dengan cara melakukan wawancara, observasi, studi pustaka, dan dokumentasi.

\section{Hasil Temuan dan Diskusi}

Komunitas Marvel Indonesia (KMI) didirikan oleh Dedi Fadim dkk pada tanggal 1 Agustus 2009. Latar belakang didirikannya komunitas ini dikarenakan banyaknya penggemar Marvel yang bersifat individual. Atas alasan tersebut, Dedi dkk pun berinisiatif untuk membentuk sebuah wadah yang dapat digunakan sebagai sarana 
tempat berkumpulnya penggemar Marvel selain itu alasan komunitas ini didirikan adalah untuk "memasyarakatkan" Marvel kepada masyarakat awam.

Komunitas Marvel bertujuan untuk menyatukan semua penggemar film-film Marvel yang sebelumnya terpisah-pisah per karakter. Komunitas ini tersebar di beberapa kota besar Indonesia seperti Jakarta, Bandung, Surabaya hingga Manado. Setiap kota memiliki satu orang yang bertanggung jawab untuk mengelola dan mengkoordinir kegiatan-kegiatan komunitas. Komunitas ini tersebar di beberapa kota besar Indonesia seperti Jakarta, Bandung, Surabaya hingga Manado. Setiap kota memiliki satu orang yang bertanggung jawab untuk mengelola dan mengkoordinir kegiatan-kegiatan komunitas. Dalam prosesnya, KMI tidak terlepas dari hadirnya sebuah komunikasi massa.

Komunikasi massa dalam pengertiannya adalah komunikasi yang dilakukan secara massal atau serentak ini memberikan kesimpulan bahwa hal ini dapat dilakukan dengan adanya bantuan dari sebuah media massa. Dalam konteks ini media massa yang akan dibicarakan adalah film, bioskop dan sosial media. Cara yang dilakukan oleh KMI adalah menonton bersama di bioskop. Selain itu, komunitas ini cenderung aktif dalam sosial media untuk memberikan informasi-informasi event yang akan diselenggarakan hingga mengajak penggemar baru untuk dapat bergabung dengan komunitas secara online.

Brand dapat dilihat sebagai entitas yang memiliki karakter sendiri yaitu nama, istilah, tanda, simbol, desain atau kombinasi dari semuanya. Reputasi sebuah brand muncul melalui sinyal-sinyal marketing yang dikirim oleh pasar dan didukung oleh taktik organisasional. Dalam hal ini, Avengers: Endgame telah menjadi brand yang dikenal melalui Marvel Studio. Hal ini tidak lepas dari reputasi bertahun-tahun yang telah dibangun dari film-film sebelumnya serta strategi promosi yang apik. Fakta menyatakan bahwa kesuksesan brand Avengers: Endgame merupakan buah dari upaya bertahun-tahun membangun cerita dan karakter sehingga film ini semakin diminati bahkan memiliki fans setia yang selalu menunggu-nunggu perilisan film tersebut.

Dalam hal ini, Avengers: Endgame hadir sebagai produk rekreasi/hiburan. Film Avengers: Endgame memberikan pengalaman yang berkesan bagi para fans yang telah mengikuti perjalanan film Marvel dalam 10 tahun terakhir. Hal ini menyatakan bahwa terbentuknya merek berdasarkan pemilihan nama, logo, simbol, desain, serta atributatribut lainnya, atau bisa juga dari kombinasi beberapa aspek yang ditujukan sebagai pembeda sebuah produk dengan produk pesaing lewat keunikannya serta segala hal yang mampu menambah nilai untuk pelanggan.

Semakin berkembangnya sebuah brand maka berkembang pula hubungan brand tersebut dengan konsumen. Hubungan brand dengan konsumen adalah sesuatu yang mengikat (emosional) antara penyedia maupun konsumen. Dalam hal Avengers: Endgame memiliki keterkaitan dengan fansnya melalui alur cerita yang emosional. Berdasarkan temuan diatas penulis mengetahui bahwa beberapa fans merasa sangat bersemangat dan larut dalam emosi saat menonton film Avengers: Endgame. Bahkan ada beberapa penonton yang menangis melihat ending tidak terduga dari film tersebut.

Dalam konteks brand, terdapat 6 dimensi yang telah di ulas yaitu atribut, manfaat, nilai, budaya, kepribadian, dan pemakai. Hasil pun menjelaskan bahwa dimensi ini sangat menjadi fondasi kuat di balik kesuksesan film Avengers: Endgame dalam mempengaruhi KMI maupun penggemar pada umumnya. Dimensi pertama adalah atribut yang mengingatkan suatu produk pada titik tertentu, atribut yang dapat ditemukan dalam film ini adalah melalui pemeran-pemerannya yang berhasil dalam membuat penonton takjub ditambah lagi dengan kepercayaan terhadap film tersebut. 
Hal ini diperkuat dengan kesukaan para penggemar dengan masing-masih tokoh yang dianggap baik dalam menjiwai perannya. Selain dari pemeran, hal yang menjadi atribut adalah proses promosi yang baik dan plot cerita yang menakjubkan sehingga mampu menarik rasa keingintahuan para penggemar untuk eksplor lebih dalam.

Kedua adalah manfaat, yang seperti diketahui bahwa sebuah brand pada akhirnya akan membawa suatu manfaat fungsional hingga emosional. Hal ini dibuktikan dengan salah satu penonton yang menonton film Avengers: Endgame yang sangat puas karena sangat spektakuler dan memberikan tanggapan yang sangat positif. Penonton ini pun mendapatkan inspirasi untuk cerita pendeknya serta gambar. Pernyataan ini menunjukkan bahwa berhasilnya pengaruh yang diciptakan oleh sebuah brand dalam memberikan manfaat untuk penggemar.

Yang ketiga adalah nilai, brand memberikan nilai mengenai suatu produk terhadap penontonnya. Dalam sajian di atas ditemukan bahwa nilai film Avengers: Endgame bagi salah satu penggemar adalah selain untuk hiburan juga ada nilai heroik yang membela kaum lemah. Yang keempat adalah budaya, budaya dalam konteks ini mengenai genre atau jenis film yang mendukung suatu brand untuk menjadi suatu identitas yang diterima oleh penggemarnya. Film Avengers: Endgame ini memiliki genre superhero, sci-fi, dan action serta menganut sistem hollywood classic yang diterbitkan secara komersial. Rasa ingin tahu orang-orang Indonesia juga menjadi faktor pendorong kesuksesan dikarenakan adanya promosi yang baik diikuti dengan plot cerita yang dibangun sedemikian rupa sehingga menarik.

Poin selanjutnya yang kelima adalah kepribadian, ketika seseorang atau konsumen sudah terikat hubungan dengan suatu brand maka orang tersebut akan mencerminkan seperti apa film tersebut mengarah, salah satu tokoh karakter yang paling menonjol dan sukses dalam perannya adalah karakter Iron Man yang diperankan oleh Robert Downey Junior. Terakhir adalah pemakai, poin ini cenderung mengarah pada jenis pelanggan yang menggunakan atau membeli produk tertentu. Penggemar memutuskan untuk menonton film Avengers: Endgame karena pada dasar kesukaan dengan film genre superhero dan mengaku telah mengikuti serial film dari awal ditambah lagi karena hype nya dari tayangan ini.

Brand relationship tidak terbatas pada fans setia saja, brand relationship memiliki model yang bervariasi, tergantung pada karakter konsumen dan seperti apa cara mereka dalam memodifikasi hubungan yang terjalin tersebut. Terdapat 5 tahap potensial dalam hubungan tersebut, dengan anekdot hubungan pertemanan, yakni potential friends, Casual friends, Close friends, Best friends hingga crucial friends. Yang terakhir adalah pemakai, faktor ini cenderung memperlihatkan konsumen yang mulai menggunakan atau membeli produk yang bersangkutan dengan produk.

Tingkatan paling dasar yaitu Potential friends (tahap mencoba brand). Dalam sajian data yang telah dipaparkan sebelumnya, seseorang menonton Avengers: Endgame karena rasa penasaran atau bisa dibilang hanya coba-coba. Namun mengakui tidak menyukai Avengers: Endgame secara keseluruhan dan tidak merasa memiliki hubungan dengan film setelah menontonnya. Hasilnya juga menyatakan bahwa tidak ada ketertarikan mengoleksi merchandise atau apapun yang bertema Avengers: Endgame. Dalam hal ini, potential friend tidak memiliki kesetiaan sama sekali terhadap suatu merek karena apapun yang ditawarkan atau diobral akan disukai. Merek dianggap sudah cukup sehingga merek berperan kecil dalam keputusan pembelian atau keputusan konsumtif. 
Tahap berikutnya adalah Casual friends atau tahap mulai menyukai brand. Dalam sajian data yang telah dipaparkan sebelumnya konsumen menonton Avengers: Endgame karena ajakan temannya dan mengaku tidak terlalu menyukai Avengers: Endgame karena film ini tergolong fiktif. Namun mengakui keberhasilan film Avengers: Endgame dalam menarik penonton yang sangat banyak. Rasa cukup puas dengan film Avengers: Endgame dan hampir tidak mengalami ketidakpuasan bahkan cenderung memilih produk tersebut atas dasar kebiasaan. Konsumen seperti ini tidak memiliki rasa ketidakpuasan untuk beralih ke merek yang lainnya. Misalkan peralihan tersebut terjadi maka dibutuhkan usaha misalnya dengan standar film yang setara namun bukan cerita fiktif, oleh karena itu tidak ada alasan bagi mereka untuk melakukannya.

Tahap berikutnya adalah Close friends pada tahapan ini konsumen mulai setia pada beberapa brand. Dalam sajian data yang telah dipaparkan sebelumnya konsumen menonton Avengers: Endgame karena rekomendasi dari anaknya. Penonton yang merasa puas, namun dibebankan biaya peralihan, yaitu biaya waktu, uang atau risiko dari sebuah merek sehubungan dengan tindakan peralihan seperti kualitas film dan alur cerita antara Marvel dan DC Comics. Selain itu, banyak penonton yang menjadi tertarik untuk bergabung dengan komunitas setelah menonton film tersebut hingga mencari tahu tentang Avengers. Agar dapat mempertahankan hubungan dengan konsumen pada tahap ini, Marvel Studio perlu mengatasi biaya peralihan dengan memberikan tawaran suatu value yang cukup besar sebagai kompensasinya, sehingga diharapkan dapat menarik minat konsumen yang masuk ke dalam kategori ini.

Tahapan selanjutnya adalah Best friends dimana pada tahap ini konsumen sudah setia pada satu brand. Dedi merupakan pendiri dan juga anggota Komunitas Marvel Indonesia yang setia mengikuti perkembangan film-film Marvel dan sangat menanti-nanti penayangan Avengers:Endgame. Menurut Dedi, film ini adalah film yang sangat dinanti-nanti oleh fans Marvel di Indonesia. Alurnya tidak bisa ditebak sehingga menimbulkan banyak teori-teori sebelum penayangannya. Preferensi Dedi didasarkan pada suatu asosiasi, seperti simbol, pengalaman baik setelah menggunakan, atau perceived quality yang tinggi dan mereka memperlakukan mereka seperti sahabat. Dedi bahkan merupakan salah satu pendiri Komunitas Marvel Indonesia yang turut andil menyatukan berbagai fans Marvel di Indonesia.

Tahap terakhir adalah Crucial friends dimana pada tahap ini konsumen sudah ketagihan pada satu brand. Dari hasil yang telah ditemukan, konsumen diklasifikasi sebagai crucial friends dari film Avengers:Endgame. Sama seperti pendiri komunitas, konsumen ini sudah menantikan penayangan film ini sejak lama dan selalu mengikuti film-film Marvel dalam 10 tahun terakhir. Ia juga mengaku mengerti alur cerita yang disajikan. Selain itu, familiar dengan aktor-aktor di film ini serta peran apa saja yang mereka mainkan. Konsumen ini memiliki keterikatan emosional yang kuat karena ia sangat bersemangat sebelum dan saat menonton film Avengers: Endgame. Selain itu ia juga mengoleksi action figure bertema superhero dari Marvel. Kecanduan terhadap brand diwujudkan juga dengan mengoleksi merchandise-merchandise bertema superhero lainnya. Ia memiliki suatu kebanggaan menjadi pengguna suatu merek. Merek tersebut sangat berpengaruh bagi nya, baik dari segi fungsi maupun sebagai cara untuk mengekspresikan siapa mereka sebenarnya. Rasa percaya yang tinggi memotivasi untuk merekomendasikan merek tersebut kepada orang lain.

Avengers: Endgame merupakan film Marvel yang paling dinanti pada 2019. Film ini mengisahkan bagaimana pahlawan super Marvel harus kembali menghadapi Thanos, yang di film sebelumnya, Avengers: Infinity War. Selain anggota KMI, orang 
- orang awam pun atau yang bukan penggemar pun terpengaruh untuk menanti film ini. Hal ini menghasilkan banyaknya orang yang mencari tahu lebih dalam tentang film.

Film Avengers: Endgame berhasil menarik penggemarnya melalui adeganadegan yang ditayangkan, antusiasme fans sangat besar dalam menantikan film ini bahkan orang awam juga menunggu-nunggu penayangan film Avengers: Endgame. Sehingga dapat dinyatakan bahwa film ini berhasil menarik untuk tetap antusias mengikuti seri-seri film superhero dari Marvel. Film ini juga layak untuk dijadikan penutupan dari rangkaian film-film Marvel selama 10 tahun.

\section{Kesimpulan}

Berdasarkan paparan diatas penulis menarik kesimpulan bahwa keberhasilan Avengers: Endgame ini tidak terlepas dari bantuan dari suatu media massa yaitu film yang kemudian menjadi sebuah brand yang masing - masing dari 6 dimensinya sudah terpenuhi dan memang dapat dikatakan sangat berhasil dalam menarik konsumennya sehingga terikat dan membentuk suatu wadah atau komunitas. Selain itu brand juga mampu menjalin suatu hubungan dengan penggemar melalui 5 tahap. Brand relationship yang terjalin antara film Avengers: Endgame dengan Komunitas Marvel Indonesia sudah berada pada tahapan best friends dan crucial friends, sulit ditemukan tahap potential friends, casual friends, dan close friends di dalam komunitas. Hal ini merupakan dampak positif yang baik bagi brand maupun komunitas karena keduanya menciptakan hubungan yang saling menguntungkan. Dalam hal ini keberadaan komunitas dirasa mendukung film Avengers: Endgame secara tidak langsung melalui event-event nonton bareng, cosplay hingga jual beli merchandise. Tentu hal ini menguntungkan bagi Marvel Studio. Konsumen dalam KMI pun merasa puas dan senang karena kegemaran mereka tersalurkan dan memiliki wadah untuk saling bertukar pikiran ataupun berdiskusi tentang brand favorit mereka.

\section{Ucapan Terima Kasih}

Penulis ingin mengucapkan terima kasih kepada seluruh narasumber penulis yang telah memberikan informasi terkait dengan penelitian ini. Dan kepada keluarga, sahabat, dan teman - teman penulis yang ikut menyemangati dan memberikan banyak dukungan dalam penulisan skripsi ini sehingga dapat selesai dengan baik dan tepat waktu.

\section{Daftar Pustaka}

Cica. (2019, Januari 16). Komunitas Marvel Indonesia, Lebih dari Sekedar September 4 , 2019. https://www.fimela.com/fimelahood/read/3871681/komunitas-marvelindonesia-lebih-dari-sekadar-penggemar

CNN Indonesia. (2019). Avengers: Endgame’ Resmi Jadi Film Terlaris Sepanjang Masa. September 4 , 2019. https://www.cnnindonesia.com/hiburan/20190721135026-220414089/avengers-endgame-resmi-jadi-film-terlaris-sepanjang-masa

Hukum Unsrat. (n.d.). UU 8/1992 Perfilman. September 4, 2019. http://hukum.unsrat.ac.id/uu/uu_8_1992.htm 
Imdb. (n.d.). Avengers: Endgame. September $\quad 9,2019$. https://www.imdb.com/title/tt4154796/

Jesslyn \& Susanto, Eko Harry. (2018). Analisis Penggunaan Label Halal pada Produk Kecantikan Brand Safi dalam Menarik Minat Beli Masyarakat. Prologia 2(2): 385-391.

Prasetyo, Harry. (2014, September 30). Lebih Dekat Bersama Komunitas Marvel Indonesia. September 10, 2019. Kabarinews. https://kabarinews.com/lebihdekat-bersama-komunitas-marvel-indonesia/70565

Pratista, Himawan. (2017). Memahami Film (Ed. 2). Yogyakarta: Montase Press.

Sadat, Andi M. (2009). Brand Belief: Strategi Membangun Merek Berbasis Kepercayaan. Jakarta: Penerbit Salemba Empat.

Sumarno, Marselli. (2008). Dasar-Dasar Apresiasi Film. Jakarta: PT. Grasindo. 